\title{
A Study on the Environmental Attitudes of Candidate Teachers
}

\author{
Öğretmen Adaylarının Çevresel Tutumlarına Yönelik Bir Araştırma
}

\author{
Elvan YALÇINKAYA* \\ Abdullah KARATAŞ ${ }^{* *}$ \\ Mustafa TALAS ${ }^{* * *}$
}

\begin{abstract}
This research aims to identify the environmental attitudes of fourth grade students of Niğde University Primary School Teaching, Science Teaching and Social Studies Teaching departments. For this purpose, the New Environmental Paradigm Scale was applied to 231 students of related departments. The parts of the scale are intended to assess the nature and human based attitudes of the candidate teachers. According to the finds it was confirmed that the nature based attitude levels of the candidate teachers are higher than their human based attitude levels. But the fact that the human based and nature based attitudes of the candidate teachers don't differ according to whether they took an environmental education course or not make it necessary to question the quality of the environmental education course provided by the Faculty of Education. As a consequence, inducing candidate teachers into a positive environmental attitude is regarded as necessary through applied and theoretically effective environmental education.
\end{abstract}

Keywords: Environmental attitude, environment education, candidate teachers

Öz: Bu araştırma, Niğde Üniversitesi Eğitim Fakültesi Sınıf Öğretmenliği, Fen Bilgisi Öğretmenliği ve Sosyal Bilgiler Öğretmenliği lisans programlarında öğrenim gören dördüncü sınıf öğretmen adaylarının çevreye karşı tutumlarını belirlemeyi amaçlamaktadır. Bu amaçla, ilgili programlarda okuyan 231 öğrenciye Yeni Çevresel Paradigma Ölçeği uygulanmıştır. Ölçekte yer alan maddeler, öğretmen adaylarının doğa ve insan merkezli yaklaşımlarını ölçmeye yöneliktir. Elde edilen bulgulara dayanılarak öğretmen adaylarının doğa merkezli tutum düzeylerinin insan merkezli tutum düzeylerinden yüksek olduğu saptanmıştır. Ancak öğretmen adaylarının insan merkezli ve doğa merkezli tutum düzeylerinin çevre dersini alıp almama durumlarına göre değişmemesi Eğitim Fakültelerinde çevre eğitimi dersinin niteliğinin sorgulanmasını gerektirmektedir. Sonuç olarak, öğretmen adaylarına uygulamalı ve teorik olarak etkin bir şekilde yapılacak çevre eğitimi ile olumlu bir çevresel tutumun kazandırılmasının gerekliliği düşünülmektedir.

Anahtar sözcükler: Çevresel tutum, çevre eğitimi, öğretmen adayları

\section{Introduction}

Today environmental problems are so severe that they threaten the future of the earth. Destroyed forests, endangered and dying species, a polluted environment and climate change describe this environmental situation very well. Human beings have and will play a significant

\footnotetext{
* Assoc. Prof., Niğde Univ., Faculty of Education, Department of Primary School Teaching, Niğde, elvanykaya@gmail.com

** Lecturer Dr., Niğde University, School of Foreign Languages, Niğde, abdullahkaratas3@gmail.com

***Assoc. Prof., Niğde Univ., Faculty of Education, Department of Primary School Teaching, Niğde, mtalas44@gmail.com
} 
role in this situation. Because they destroy the environment for the sake of their own benefit and use the environment as a tool, destroying environmental values. In fact they cut their own throat through their insensible behavior towards the environment, since all creatures, including human beings cannot be thought of without the environment they inhabit and which they need for their own survival.

Plants, animals and the living organism of the biosphere cannot be abstracted from their environment. All living creatures obtain the entire supply of physical materials, those necessary for their food, beverage, shelter and themselves from their environment. Air, water and earth are truly important for all living creatures (Sahgal, \& Sahgal, 2009, 96). Nature is really important for creatures to be able to continue living their lives. Nature can be explained as the physical, biological, social, economic and cultural environment in which people and other creatures interact with each other (Republic of Turkey Environmental Law). Everything surrounding and affecting an organism forms its environment (Sahgal, \& Sahgal, 2009, 69). As can be understood from these definitions, the environment possesses a vital sense for all creatures and surrounds them in every aspect. Yet people spoil that harmony seeking their own benefits.

Recently environmental problems have taken a place at the top of the national and international adgenda (Ogunbiyi, \& Ajiboye, 293, 2009). The unconscious and wrong practices against environmental values bring about many problems (Talas, \& Karataş, 2012, 108). Just because, seeing and using the environment as only an obstacle in the way, brings many environmental disasters with it. Some very important problems such as pollution and global warming threaten the future of the world. Consumption based homocentric views speed up this situation. However, people should learn how to be content with what they have, instead of increasingly consuming more and more, and they should also learn how to pull their weight through not remaining insensitive to environmental problems. This responsibility can be assigned them through environmental education. In this respect, the responsibility rests upon the shoulders of the teachers who shape the future and educate children. The environment thematic courses will be lead by the teachers, courses which they took when they were candidate teachers. Candidate teachers will be able to transmit their environmentally friendly attitudes and behaviors to their own students when they start working. Thus, the generation raised by them will behave with responsibility towards their environment. In this context, the environmentally friendly attitude and behavior given to candidate teachers through the environmental education at the faculty of education is very important in terms of generating a healthier and more livable world.

The aim of environment education is to raise environmentally friendly individuals, those interested, informed about the environment and environmental problems, conscious and willing to attempt to solve these problems, evaluating environment problems and creating applicable solutions to the defined problems (Pooley, \& O’Connor, 2000, 711). In accord with this purpose, environment education comprises education about the environment and for the environment in environment education. Education in the environment enables people to develop sensibility and information concerning their own environment and social system. Education for the environment motivates people to work developing the environment (Meredith, et alii., 2000, 4). Based upon these definitions, environment education can be defined as developing environmental consciousness in every part of society, bringing about sensitive, positive and permanent behavioral change and procuring participation in solving natural, historical, cultural and socio-aesthetic problems (Environment Atlas of Turkey). In other words environment education can be expressed as: a period of developing understanding and developing based upon effective education leading to an awareness of and solutions sought for environmental problems, 
politics and administration (Markle, 2008, 14).

The aim of environment education is to produce permanent solutions to environmental problems (Pooley, \& O'Connor, 2000, 712). In this respect the environmentally friendly attitude and behavior of children informed through environment education will guide them in protecting and developing the environment in the future. So, they will not ignore environmental values in their plans and projects in different kinds of professions and they will be respectful towards environmental values throughout their lives.

According to Pandey (Pandey, 2006, 191) it is possible to bring children into environmentally friendly behavior and with environmentally positive attitudes through environment education. Hence, it is necessary to make living in as healthy and safe planet the target, the environmental attitude and the behavior of the students important and it is necessary to make an effort in this subject (Evans, et alii, 2007, 636). Despite the fact that necessary precautions are taken through disincentive policies and laws, there won't be any permanent solutions unless the attitude and behavior of the people change and this change can only be made through environmental education. In particular, bringing primary school age children into a positive environmental attitude is a part of the solution, and it is an assurance of a safer future.

\section{The Aim and Importance of this Research}

Candidate teachers in whom a positive environmental attitude has been inculcated will transmit this positive attitude to their students when they start working. The children, especially the younger children, who have a positive attitude and behavior towards the environment, will be able to lighten the weight of the environmental problems in the future. Within this scope, under these circumstances, Faculties of Education are very important because the teachers who shape the youth of the future are educated in these institutions. This research was carried out in the Niğde University Faculty of Education. It aimed to establish the environmental attitudes of fourth grade candidate teachers studying at the Primary School Teaching, the Science Teaching and the Social Studies Teaching departments through examining their attitudes according to some variables. For this purpose, answers were sought to the following questions:

- Does the level of the candidate teachers' human based environmental attitudes vary according to their gender?

- Does the level of the candidate teachers' nature based environmental attitudes vary according to their gender?

- Does the level of the candidate teachers' human based environmental attitudes vary in terms of whether or not they took environment courses ?

- Does the level of the candidate teachers' nature based environmental attitudes vary in terms of whether or not they took environment courses?

- Does the level of the candidate teachers' human based environmental attitudes vary according to their department?

- Does the level of the candidate teachers' nature based environmental attitudes vary according to their department?

- Does the level of the candidate teachers' human based environmental attitudes vary according to their education type (daytime/evening)?

- Does the level of the candidate teachers' nature based environmental attitudes vary according to their education type (daytime/evening)?

- Does the level of the candidate teachers' human based environmental attitudes vary according to their long term place of residence? 
- Does the level of the candidate teachers' nature based environmental attitudes vary according to their long term place of residence?

- Does the level of the candidate teachers' human based environmental attitudes vary in terms of their being a member of an environmental civil society organization or not?

- Does the level of the candidate teachers' nature based environmental attitudes vary in terms of their being a member of an environmental civil society organization or not?

\section{Research Method}

This research's model is the relational screening model. According to Karasar (2006) the relational screening model aims at identifying the existence and/or level of change between two or more variants, doesn't show real cause and effect relation and enables an estimate of the other if one variant's situation is definite. Crano and Brewer (2002) indicate that in this model the aim is to present the existence and levels of the relations between dependent and independent variants. In this scope, there are two variances; dependent and independent variances. The dependent variance of the research is the candidates' human and nature based attitudes; and independent variances are their gender, the department where they are studying, education type, whether or not he/she took an environment education course, whether he/she is a member of any environmental civil society organization and place of long term residence. In this research the matter of if the candidates' environmental attitudes differ, or not according to these specific variables was assessed.

\section{Study Group}

The study group for this research was formed of the senior class students of Niğde University Faculty of Education Primary School Department (Primary School Teaching, Science Teaching and Social Studies Teaching) in the 2012-2013 academic year. Participation was voluntary. The personal information of the participants is given in Table 1. Evident from Table 1 there were 231 candidate teachers who participated in this study.

Table 1. Some information about the study group

\begin{tabular}{|c|c|c|c|}
\hline \multicolumn{2}{|l|}{ Personal Information } & $\mathbf{N}$ & $\%$ \\
\hline Department & $\begin{array}{l}\text { Primary School Teaching } \\
\text { Science Teaching } \\
\text { Social Studies Teaching } \\
\text { Total }\end{array}$ & $\begin{array}{c}83 \\
108 \\
40 \\
231\end{array}$ & $\begin{array}{l}35.9 \\
46.8 \\
17.3 \\
100\end{array}$ \\
\hline Gender & $\begin{array}{l}\text { Female } \\
\text { Male } \\
\text { Total }\end{array}$ & $\begin{array}{c}137 \\
94 \\
231\end{array}$ & $\begin{array}{l}59.3 \\
40.7 \\
100\end{array}$ \\
\hline Education Type & $\begin{array}{l}\text { Daytime Education } \\
\text { Evening Education } \\
\text { Toplam }\end{array}$ & $\begin{array}{c}151 \\
80 \\
231\end{array}$ & $\begin{array}{l}65.4 \\
34.6 \\
100\end{array}$ \\
\hline Taking Environment Courses & $\begin{array}{l}\text { Yes } \\
\text { No } \\
\text { Total }\end{array}$ & $\begin{array}{c}182 \\
49 \\
231\end{array}$ & $\begin{array}{l}78.8 \\
21.2 \\
100\end{array}$ \\
\hline $\begin{array}{l}\text { Being a Member of an } \\
\text { Environmental Civil Society } \\
\text { Organization }\end{array}$ & $\begin{array}{l}\text { Yes } \\
\text { No } \\
\text { Total }\end{array}$ & $\begin{array}{c}10 \\
221 \\
231\end{array}$ & $\begin{array}{r}4.3 \\
95.7 \\
100\end{array}$ \\
\hline Place of Long Term Residence & $\begin{array}{l}\text { Village } \\
\text { Town } \\
\text { Town Center } \\
\text { City Center } \\
\text { Total }\end{array}$ & $\begin{array}{c}29 \\
23 \\
69 \\
110 \\
231\end{array}$ & $\begin{array}{l}12.6 \\
10.0 \\
29.9 \\
47.6 \\
100\end{array}$ \\
\hline
\end{tabular}




\section{Data Collecting and Analysis}

The data collection tool for this research was the New Environmental Paradigm Scale with the scale as developed by Dunlap and others (2000). The validity and safety studies of this scale were made by some researchers such as Furman (1998); Işıldar (2008); Alnıaçık and Koç, (2009). The scale contains of two parts. There are questions about personal information (gender, department that they are studying, education type, whether or not he/she took an environment education course, whether he/she is a member of any environmental civil society organization and what place was the long term residence) in the first part. In the second part there are some questions to identify the level of environmental attitude. The questions about the environmental attitude enable us to assess the nature based and the human based approaches. There are 15 questions in the scale. 8 of them assess the natural based approach and 7 of them assess the human based approach. These questions are of the fivefold likert type. The data was analyzed by means of a package program called SPSS 16.0 (Statistical Program for Social Sciences). T-test, variance analysis and descriptive statistics were used in the analysis of the data.

\section{Findings and Comments}

The findings from the sub-problems from the answers of the participants are shown in the tables. The findings obtained by analyzing the environmental attitude of the candidate teachers in terms of their gender variance are shown at Table 2.

Table 2. Difference in environmental attitudes of candidate teachers in terms of gender

\begin{tabular}{|l|c|c|c|c|c|c|c|}
\hline \multicolumn{1}{|c|}{ Dimensons } & Gender & N & $\bar{X}$ & S & sd & t & P \\
\hline Nature Based & Woman & 137 & 4.36 & 0.39 & 229 & 0.94 & 0.346 \\
\cline { 2 - 9 } Environmental Attitude & Man & 94 & 4.30 & 0.48 & & & \\
\hline Human Based & Woman & 137 & 2,68 & 0.69 & 229 & 0.40 & 0.689 \\
\cline { 2 - 9 } Environmental Attitude & Man & 94 & 2.71 & 0.67 & & & \\
\hline
\end{tabular}

As seen from the statistical information in Table 2, there isn't any significant difference between the nature based environmental attitudes of the candidate teachers $\left(\mathrm{t}_{(229)}=0.94 \mathrm{p}>0.05\right)$ and the human based environmental attitudes $\left(\mathrm{t}_{(229)}=0.40 \mathrm{p}>0.05\right)$ according to gender. It can be said from the findings obtained that there isn't any determinative factor of gender on the candidate teachers' environmental attitudes.

The difference as to whether or not the candidates took an environment education course is shown in Table 3.

Table 3. Difference in the candidate teachers environmental attitudes in terms of whether or not they took environment courses

\begin{tabular}{|c|c|c|c|c|c|c|c|}
\hline Dimensons & $\begin{array}{c}\text { Taking } \\
\text { Environment } \\
\text { Course }\end{array}$ & N & $\bar{X}$ & S & sd & t & P \\
\hline $\begin{array}{c}\text { Nature Based } \\
\text { Environmental } \\
\text { Attitude }\end{array}$ & Taking & 182 & 4.32 & 0.41 & 229 & 0.95 & 0.342 \\
\cline { 2 - 8 } & Not Taking & 49 & 4.39 & 0.49 & & & \\
\hline $\begin{array}{c}\text { Human Based } \\
\text { Environmental } \\
\text { Attitude }\end{array}$ & Taking & 182 & 2.69 & 0.67 & 229 & 0.11 & 0.913 \\
\cline { 2 - 8 } & Not Taking & 49 & 2.70 & 0.73 & & & \\
\hline
\end{tabular}


When Table 3 is analyzed it is seen that there isn't any significant difference between nature based environmental attitudes $\left(\mathrm{t}_{(229)}=0.95 \mathrm{p}>0.005\right)$ and human based environmental attitudes $\left(\mathrm{t}_{(229)}=0.10 \mathrm{p}>0.005\right)$ according to the fact that whether or not they took the environment courses. There isn't any effect on both nature based and human based environmental attitudes when they take environment courses. Besides, as Sever and Yalçınkaya (2012) indicates the clauses on human based approach are the clauses those show that environmental awareness isn't fully developed. That's why low grades are expected for the questions assessing human based approach.

The ANOVA results about the differences in terms of the department of the candidate teachers are shown at Table 4.

Table 4. Differences of the environmental attitudes of the candidate teachers in terms of departments

\begin{tabular}{|l|l|c|c|c|c|c|c|}
\hline \multicolumn{1}{|c|}{ Dimensions } & \multicolumn{1}{c|}{ Department } & N & \multicolumn{1}{c|}{$\bar{X}$} & \multicolumn{1}{c|}{ S } & \multicolumn{1}{|c|}{ F } & P & Diference \\
\hline \multirow{2}{*}{$\begin{array}{l}\text { Nature Based } \\
\text { Environmental } \\
\text { Attitude }\end{array}$} & Primary School Teaching & 83 & 4.24 & 0.40 & 16.152 & $0.000^{*}$ & $2-1$ \\
\cline { 2 - 9 } & Social Studies Teaching & 108 & 4.49 & 0.40 & & & $2-3$ \\
\cline { 2 - 9 } & Science Teaching & 40 & 4.11 & 0.41 & & & \\
\hline \multirow{2}{*}{$\begin{array}{l}\text { Human Based } \\
\text { Environmental } \\
\text { Attitude }\end{array}$} & Primary School Teaching & 83 & 2.79 & 0.74 & 3.269 & $0.040^{*}$ & $1-2$ \\
\cline { 2 - 9 } & Social Studies Teaching & 108 & 2.57 & 0.66 & & & $3-2$ \\
\cline { 2 - 9 } & Science Teaching & 40 & 2.82 & 0.54 & & & \\
\hline
\end{tabular}

${ }^{*} \mathrm{p}<0.05$ categories: "Primary school teaching $=1$; Social studies teaching= 2; Sciences teaching=3"

As a result of the $\mathrm{F}$ tests it is seen that there are some differences in the nature based environmental attitudes according to the departments chosen by the candidate teachers $(\mathrm{F}=16.152 \mathrm{p}<0.05)$. When the source of this difference is searched for, according to the Scheffe test result; there is a significant difference between those candidate teachers studying Science Teaching and those candidate teachers studying Social Studies Teaching and those candidate teachers studying Primary School Teaching.

The significant difference in nature based attitude is in favor of candidate teachers studying Social Studies Teaching, it is seen that the difference is between the candidate teachers studying Primary School Teaching and Science Teaching. As can be understood from the arithmetic averages of the candidate teachers, the arithmetic average of candidate teachers studying Social Studies Teaching is 4.49. The arithmetic average of candidate teachers studying Primary School Teaching is 4.24 and the average of teacher candidates studying Science Teaching is 4.11.

As a result of the $\mathrm{F}$ tests it is seen there are also some differences in human based environmental attitudes according to the departments of the candidate teachers $(F=3.269 \mathrm{p}<0.05)$. When the source of the difference is searched for, the significant difference concerning the human based attitude is in favor of the candidate teachers studying Science Teaching, it is seen that the difference is between the candidate teachers studying Social Studies Teaching. The other difference is between candidate teachers studying Primary School Teaching and Social Studies Teaching and it is in favor of Primary School Teaching. The highest average of the human based studies is 2.82 and it belongs to the candidate teachers of Science Teaching. The arithmetic average of candidate teachers studying Primary School Teaching is 2.79 and the average for Social Studies Teaching is 2.57. From these findings, it can be said the students of Social Study Teaching look less human centered towards the environment than the students of other departments.

The findings as to if environmental attitude differ in terms of education type are shown in Table 5. 
Table 5. Differences of candidate teachers environmental attitude in terms of education type

\begin{tabular}{|l|l|c|c|c|c|c|c|}
\hline Dimensions & Education Type & $\mathbf{N}$ & $\bar{X}$ & $\mathbf{S}$ & sd & t & P \\
\hline $\begin{array}{l}\text { Nature Based } \\
\begin{array}{l}\text { Environmental } \\
\text { Attitude }\end{array}\end{array}$ & Daytime & 151 & 4.28 & 0.40 & 229 & 2.42 & $0.016^{*}$ \\
\cline { 2 - 7 } & Evening & 80 & 4.43 & 0.46 & & & \\
\hline $\begin{array}{l}\text { Human Based } \\
\text { Environmental } \\
\text { Attitude }\end{array}$ & Daytime & 151 & 2.65 & 0.67 & 229 & 1.46 & 0.143 \\
\cline { 2 - 7 } & Evening & 80 & 2.78 & 0.69 & & & \\
\hline$p<05$
\end{tabular}

There is a significant difference in the nature based attitude according to education type $\left(\mathrm{t}_{(229)}=2.42 \mathrm{p}<0.05\right)$. The nature based attitude average of candidate teachers studying at daytime education is 4.28 and the average of evening education students is 4.43 . From this, it can be said the environmental attitudes of candidate teachers studying in evening education is more nature based than those studying in day time education. There is no statistical significant difference in the human based environmental attitudes of the participants according to education type $\left(\mathrm{t}_{(229)}=1.46\right.$ $\mathrm{p}>0.005$ ). Thus, it is seen that education type isn't a significant variant in the human based environmental attitudes of candidate teachers.

The ANOVA results as to if the environmental attitudes of the participants differ in terms of their place of long term residence is shown in Table 6.

Table 6. Differences of candidate teachers' environmental attitudes in terms of their long term place of residence

\begin{tabular}{|l|l|l|l|l|l|l|}
\hline \multirow{2}{*}{ Dimensions } & Residential Area & $\mathbf{N}$ & $\bar{X}$ & $\mathbf{S}$ & $\mathbf{F}$ & P \\
\hline \multirow{3}{*}{$\begin{array}{l}\text { Nature Based } \\
\text { Environmental Attitude }\end{array}$} & Village & 29 & 4.37 & 0.43 & 1.333 & 0.265 \\
\cline { 2 - 6 } & Town & 23 & 4.45 & 0.37 & & \\
\cline { 2 - 7 } & Town Center & 69 & 4.37 & 0.39 & & \\
\cline { 2 - 7 } & City Center & 110 & 4.28 & 0.46 & & \\
\hline \multirow{3}{*}{$\begin{array}{l}\text { Human Based } \\
\text { Environmental Attitude }\end{array}$} & Village & 29 & 2.69 & 0.51 & 0.331 & 0.803 \\
\cline { 2 - 7 } & Town & 69 & 2.63 & 0.93 & & \\
\cline { 2 - 7 } & Town Center & 110 & 2.74 & 0.61 & & \\
\hline
\end{tabular}

As a result of the research it is seen there is no significant difference at $\mathrm{p}>0.05$ level in the nature based environmental attitude level of the candidate teachers $(\mathrm{F}=1.333 \mathrm{p}>0.005)$ and their human based environmental attitude level ( $\mathrm{F}=0.331 \mathrm{p}>0.005)$.

The findings concerning the candidate teachers' membership in an civil society organization environmental in terms of variance are shown in Table 7.

Table 7. Differences in the candidate teachers' environmental attitudes in terms of their being a member of a civil society environmental organization or not

\begin{tabular}{|l|c|c|c|c|c|c|c|}
\hline Dimensions & $\begin{array}{c}\text { Being a Member of an Civil Society } \\
\text { Environmental Organization }\end{array}$ & $\mathbf{N}$ & $\bar{X}$ & S & sd & t & P \\
\hline $\begin{array}{l}\text { Nature Based } \\
\text { Environmental } \\
\text { Attitude }\end{array}$ & Yes & 10 & 4.45 & 0.40 & 229 & 0.82 & 0.409 \\
\cline { 2 - 8 } & No & 221 & 4.33 & 0.43 & & & \\
\hline $\begin{array}{l}\text { Human Based } \\
\text { Environmental } \\
\text { Attitude }\end{array}$ & Yes & 10 & 2.82 & 0.34 & 229 & 0.61 & 0.539 \\
\cline { 2 - 8 } & No & 221 & 2.69 & 0.69 & & & \\
\hline
\end{tabular}


As a result of the tests it was found there was no significant difference at $\mathrm{p}>0.05$ level in both the nature based environmental attitudes of candidate teachers $\left(\mathrm{t}_{(229)}=0.82 \mathrm{p}>0.005\right)$ and the human based environmental attitudes $\left(\mathrm{t}_{(229)}=0.61 \mathrm{p}>0.005\right)$ according to if the candidate teachers were a member of a civil society environmental organization or not.

\section{Result and Suggestions}

The real reasons for environmental problems today are the life-styles adopted by people, their value judgments and their attitudes. That is why, an education which will change today's people's outlook towards nature, shape their values and attitudes is very important (Gokçe, Kaya, Aktay, \& Özden, 2007, 454). It can be said that it is possible reform terminal behaviors and attitudes through environmental education (Hoerisch, 2002). In this research the environmental attitudes in terms of different variants of candidate teachers studying at the Niğde University Faculty of Education, Primary School Teaching, Science Teaching and Social Studies Teaching were researched and the results of this research are given below:

It was confirmed as a result of this research that the nature based environmental attitude of the candidate teachers of Niğde University Faculty of Education is higher than their human based environmental attitude. The nature based environmental attitude of candidate teachers is very important in bringing their students towards a nature based attitude and behavior when they graduate (Hicks, 2004, 41-42).

In the research it was found there was no any significant difference from gender in nature based and human based environmental attitudes. In the research of Sever and Yalçınkaya (2012) any significant difference between their gender and attitude was determined. But in the research of Erol and Gezer (2006) there is a significant difference in environmental studies according to gender. This significant difference is in favor of females. In similar research by Gökçe, et alii. (2007) the difference was also in favor of the females.

Another result of this research is that there was no any significant difference in terms of if the candidate teachers took an environment course or not and this lack of difference between the levels of both nature based and human based environmental attitudes of candidate teachers is striking. There isn't any significant difference between those students who took the environmental courses and those students who didn't take environmental courses in the study carried on by Deniş and Genç (2007) among the students of Primary School Teaching. Yet the aim of the environment courses is to induce, educate and enable students to develop a positive attitude towards the environment (Pooley, \& O’Conor, 2007, 711). The fact that there was no difference in the environmental attitudes of the students, between those students who took the environment courses and those students who didn't take the environment courses, makes it necessary to question both the content and the structure of the environment course.

According to the data obtained from this research, the nature based environmental attitude level of candidate teachers differ according to their departments. This difference is in favor of the Social Studies Teaching students in comparison to both the Primary School Teaching and Science Teaching students. It is evident the human based environmental level of the Science Teaching candidate teachers is higher than the students of Social Studies Teaching and Primary School Teaching.

From this research it is clear that the nature based environmental attitude level of the evening education students was higher than the students of daytime education. But there was no significant difference in the human based environmental attitudes of candidate teachers in terms of education type. 
It is seen from this research that there was no significant difference in the attitudes of the participants in terms of their place of long term residence. According to the research results of Erol and Gezer (2006) the environmental attitude level of the students doesn't differ due to the place of long term residence.

It was also determined as a result of this research that there was no difference in both the nature based and the human based environmental attitude level of candidate teachers in terms of being a member of a civil society environmental organization or not. Another significant point is that the number of teacher candidates who are members of civil society environmental organizations is very low. Only 10 of the participants recorded they were members of any civil society environmental organization. Similar results were obtained in the research of Oğuz, Çakci and Kavas (2010). Civil society environmental organizations carry on their activities voluntarily without any expectation of profit in order to protect the environment and improve society (Shah, 2005). In this sense, it is necessary to encourage and support candidate teachers, those who will shape the future of society, to become members of any civil society environmental organization. By this means they will be able to attend activities to develop and protect the environment. For this reason being a member of a civil society environmental organization can be really helpful for candidate teachers to raise their knowledge and experience and accordingly to develop a deeper and positive environmental attitude. The following suggestions can be made according to the findings from this research:

- Effective and intense environment education will be able to guide candidate teachers to bring their students to the necessary environmental attitude and behavior when they become teachers.

- Environment education should be given not only theoretically but also practically at Faculties of Education. Candidate teachers should be supported in designing, protecting and developing themed projects and attending social activities.

- Environmental education should begin at pre-school stage and it should continue in every grade. That's why the curriculum of Faculties of Education should be reviewed and some renovations can be made to develop the environmental awareness of candidate teachers.

- Some activities to raise environmental attitude levels can be carried out through aligning civil society environmental organizations with Faculties of Education.

- Candidate teachers can be guided to civil society activities concerning the environment.

- Environmental attitude levels of candidate teachers should be increased through courses taught at the Faculty of Education.

- In any further research; the reasons for different environmental attitude levels in different departments may be established.

\section{REFERENCES}

Alnıaçık, Ü., \& Koç, F. (2009). "Yeni Çevresel Paradigma Ölçeği ile Üniversite Öğrencilerinin Çevreye Yönelik Tutumlarının Değerlendirilmesi”. Bölgesel Kalkınma Kongresi, Balıkesir Üniversitesi, 14-16 Kasım 2009, Balıkesir.

Crano, W., D., \& Brewer, M., B. (2002). Principles and Methods of Social Research. New Jersey: Lawrence Erlbaum Associates Publishers.

Deniş, H. \& Genç, H. (2007). "Çevre Dersini Alan ve Almayan Sınıf Öğretmenliğindeki Öğrencilerinin Çevreye İlişkin Tutumları ve Çevre Bilimi Dersindeki Başarılarının Karşılaştııılması”. Mehmet Akif 
Ersoy Üniversitesi Eğitim Fakültesi Dergisi, 20, 20-26.

Oğuz, D., Çakci, I., \& Kavas, S. (2010). "Environmental Awareness of University Students in Ankara, Turkey”. African Journal of Agricultural Research, 5 (19), 2629-2636.

Dunlap, R., E., Van Liere, K., D., Mertig, A., G., \& Jones, R., E. (2000). "Measuring Endorsement of the New Ecological Paradigm: A Revised NEP Scale”. Journal of Social Issues, 56, 425-442.

Environment Atlas of Turkey. Republic of Turkey, Ministry of Environment and Forestry, Retrieved from http://web.deu.edu.tr/atiksu/ana35/ana35.html

Erol, G. H., \& Gezer, K. (2006). "Sınıf Öğretmenliği Öğretmen Adaylarının Çevreye ve Çevre Sorunlarına Yönelik Tutumları”. International Journal Of Environmental and Science Education, 1 (1), 65-77.

Evans, G., W., Brauchle, G., Haq, A., Stecker, R., Wong, K., \& Shapiro, E. (2007). "Young Children's Environmental Attitudes and Behaviors". Journal of Environment and Behavior, 39 (5), September, 635-659.

Furman, A. (1998). "A Note on Environmental Concern in a Developing Country Results from an İstanbul Survey”. Environment \& Behavior, 30, 520-534.

Gökçe, N., Kaya, E., Aktay, S., \& Özden, M. (2007). "İlköğretim Öğrencilerinin Çevreye Yönelik Tutumları". İlköğretim Online, 6 (3), 452-468.

Hicks, D. (2004). “Education Studies”. Ed.: Stephen Ward. Education and Environment, 41-42. London: Routledge Falmer.

Hoerisch, H. (2002). "A Comparative Study on Environmental Awareness and Environmentally Beneficial Behavior in India”. April, CMS ENVIS Centre, Centre For Media Studies, New Delhi, India.

Işıldar, G. (2008). "Meslek Yüksekokulları Boyutunda Çevre Eğitiminin Çevreci Yaklaşımlar ve Davranışlar Üzerindeki Etkilerinin Değerlendirilmesi”. Türk Eğitim Bilimleri Dergisi, 6 (4), 759-778.

Karasar, N. (2006). Bilimsel Araştırma Yöntemi. Ankara: Nobel.

Markle, A. J. (2008). Adult Environmental Education Programming in the Twin Cities Metropolitan Area Related to Critical Natural Resource Issues. Eisenhower Parkway-USA: ProQuest LLC.

Meredith, J., Cantrell, D., Conner, M., Evener, B., Hunn, D., \& Spector, P. (2000). Best Practices for Environmental Education: Guidelines for Success. Ohio-USA: Environmental Education Council of Ohio.

Pandey, V. C. (2006). Environmental Education. India: Isha Books.

Pooley, J., A., \& O’Connor, M. (2000). Environmental Education and Attitudes: Emotions and Beliefs are What is Needed". Journal of Environment and Behavior, 32 (5), 711-723.

Ogunbiyi, J., O., \& Ajiboye, J. (2009). Pre-Service Teachers' Knowledge of and Attitudes to Some Environmental Education Concepts Using Value Education Strategies". The Anthropologist, International Journal of Contemporary and Applied Studies of Man, 11 (4), 293-301.

Republic of Turkey Environmental Law. Law No: 2872, Date of Adoption: 09.08.1983, Official Gazette of Publication:11 August 1983, Issue:18132, Volume: 22, p. 499.

Sahgal, A., C., \& Sahgal, M. (2009). Living Science 6 Silver Jubilee Edition. India: Ranta Sagar.

Sever, R., \& Yalçınkaya, E. (2012). "Sınıf Öğretmeni Adaylarının Çevresel Tutumlarının İncelenmesi". Marmara Coğrafya Dergisi, Temmuz, 26, 1-15.S.

Shah, A. (2005). "Non-governmental Organizations on Development Issues". Retrieved from http://www. globalissues.org/article/25/non-governmental-organizations-on-development-issues.

Talas, M., \& Karataş, A. (2012). "Çevre Bilincinin Geliştirilmesinde Topluma Hizmet Uygulamaları Dersinin Önemi: Niğde Üniversitesi Sınıf Öğretmenliği Programı Örneği”. Zeitschrift für die Welt der Türken, 4 (1), 107-124. 